\title{
REFORMA BRYTYJSKIEJ IZBY LORDÓW W ŚWIETLE RAPORTU KOMISJI LORDA SPIKERA Z 2017 ROKU
}

\author{
Łukasz Danel \\ Uniwersytet Ekonomiczny w Krakowie \\ Katedra Studiów Politycznych \\ e-mail: lukasz.danel@uek.krakow.pl \\ ORCID: 0000-0001-9715-3377
}

\begin{abstract}
Streszczenie: Artykuł poświęcony jest analizie najnowszej koncepcji dotyczącej reformy Izby Lordów. Koncepcja ta pojawiła się w październiku 2017 roku wraz z publikacją Raportu Komisji Lorda Spikera. Raport ten zawiera rekomendacje, których celem jest ograniczenie liczby członków Izby Lordów, co jest obecnie newralgicznym problemem tej izby brytyjskiego parlamentu.

Autor rozpoczyna od analizy stanu faktycznego i okoliczności, które doprowadziły do ożywienia się dyskusji nad reformą Izby Lordów. Następnie przedstawia najważniejsze założenia Raportu Komisji Lorda Spikera, poddaje je ocenie, a także próbuje udowodnić tezę, że istnieje małe prawdopodobieństwo, że wejdą one w życie, przynajmniej w tej formie. Wynika to zarówno z uwarunkowań wewnętrznych związanych z brytyjskim porządkiem konstytucyjnym, jak i przyczyn zewnętrznych, gdyż przed Zjednoczonym Królestwem stoją dziś wielkie wyzwania na arenie międzynarodowej. $\mathrm{Z}$ tego powodu kwestie zmian ustrojowych uchodzą dziś w oczach brytyjskich polityków za drugorzędne.
\end{abstract}

Słowa kluczowe: reforma, Izba Lordów, parlament, Wielka Brytania, tradycja, konstytucja

\section{WPROWADZENIE}

Izba Lordów jest bez wątpienia jedną z najciekawszych i zarazem najbardziej osobliwych izb parlamentu we współczesnym świecie. Jej długa tradycja, głębokie zakorzenienie w brytyjskim systemie politycznym, a także przekonanie, że spełnia w ramach tego systemu bardzo pożyteczną funkcję, wpływają w sposób oczywisty na jej trwałość. Na przestrzeni XX wieku została ona co prawda poddana kilku reformom, jednakże wiele propozycji zmian zostało - z różnych 
względów - zablokowanych. Brytyjscy politycy albo nie uznawali tych proponowanych zmian za potrzebne czy priorytetowe, albo na przeszkodzie stawały względy natury politycznej, ewentualnie nadmierne przywiązanie do tradycyjnych rozwiązań - przez wielu traktowanych wręcz jako świętość.

W pierwszej połowie XX wieku - wskutek ustaw z 1911 i 1949 roku - doszło do znacznego osłabienia pozycji ustrojowej oraz uprawnień Izby Lordów, a co za tym idzie - wprowadzenia wyraźnej asymetrii w ramach dwuizbowego parlamentu brytyjskiego. Druga połowa XX wieku natomiast była świadkiem wielu fundamentalnych zmian związanych ze składem osobowym Izby - wprowadzono parostwa dożywotnie, umożliwiono zasiadanie w Izbie kobietom czy wreszcie - u schyłku tego stulecia - w sposób bezprecedensowy zredukowano liczbę parów dziedzicznych.

Wszystkie te reformy nie rozwiązały jednak największego problemu Izby Lordów, jakim jest nadmierna liczba jej członków. Źródłem tego problemu jest przede wszystkim system powoływania w skład Izby nowych parów dożywotnich, który daje w tym względzie w zasadzie nieograniczone możliwości szefom brytyjskich rządów, którzy z kolei bardzo często nie potrafią w tym względzie okazać jakże potrzebnej wstrzemięźliwości. Skutek tego jest natomiast taki, że ta największa w Europie (a druga największa na świecie) izba parlamentu nie jest w stanie pracować tak efektywnie jak powinna, znacząco rosną koszty jej utrzymania, a w Pałacu Westminsterskim najzwyczajniej w świecie brakuje miejsca, aby zapewnić wszystkim lordom godne warunki pracy - zarówno na sali obrad, jak i poza nią.

$\mathrm{W}$ ostatnich dwóch dekadach kilkukrotnie próbowano się z tym problemem mierzyć, ale praktycznie wszystkie propozycje, których celem było albo radykalne zmniejszenie liczby parów, albo całkowita (lub chociaż częściowa) zmiana sposobu kreowania składu osobowego izby, nie znalazły poparcia wśród polityków. I choć wagę problemu wielokrotnie podkreślali sami lordowie, przedstawiciele największych brytyjskich partii czy wreszcie eksperci od prawa konstytucyjnego, rozwiązania, które udało się przyjąć, przyniosły tylko kosmetyczne zmiany.

Wiele wskazuje jednak na to, że sytuacja wreszcie dojrzała do przeprowadzenia bardziej gruntownych zmian. Dowodem na to jest opublikowany końcem października 2017 roku raport specjalnie w tym celu powołanej przez Lorda Spikera komisji, której zadaniem było opracowanie propozycji zmierzających do rozwiązania problemu dotyczącego liczebności Izby Lordów. Raport ten zawiera rekomendacje, które - biorąc pod uwagę brytyjskie podejście do zmian instytucjonalnych i wspomniane wcześniej zamiłowanie do tradycji ustrojowej - można uznać za absolutnie rewolucyjne.

Artykuł stanowi próbę oceny, czy przedstawione w tym raporcie propozycje zmian idą w dobrym kierunku, a także na ile są to propozycje realne, czyli innymi słowy na ile prawdopodobne jest to, że wejdą one w życie. W tym celu autor posłużył się przede wszystkim metodą analizy instytucjonalno-prawnej, wykorzystując również elementy metody historycznej oraz - w odniesieniu do najbardziej bieżących kwestii - metody analizy treści. Przeprowadzenie analizy zarysowanego 
powyżej problemu badawczego dało autorowi podstawy do potwierdzenia tezy, że mimo iż liczebność Izby Lordów jest dziś jednym z kluczowych problemów związanych z funkcjonowaniem i pracą parlamentu brytyjskiego, propozycje Komisji Lorda Spikera nie zostaną wprowadzone w życie, a już na pewno nie w takim kształcie, jak zostały opisane w raporcie. Teza taka wydaje się uprawniona, biorąc pod uwagę uwarunkowania zarówno wewnętrzne (czynniki polityczne, prawnokonstytucyjne itp.), jak i zewnętrzne, czyli związane z wyzwaniami, przed którymi stoi państwo brytyjskie na arenie międzynarodowej i które to wyzwania mogą zepchnąć na dalszy plan propozycje zmian ustrojowych.

\section{SPECYFIKA IZBY LORDÓW}

Na tle innych izb parlamentu występujących w skonsolidowanych demokracjach zachodnioeuropejskich Izba Lordów jawi się jako instytucja dość nietypowa, a pod wieloma względami wręcz mocno osobliwa. Zarówno dla badacza współczesnych systemów politycznych, jak i dla postronnego obserwatora otaczającej nas rzeczywistości społeczno-politycznej w pierwszej kolejności z Izbą Lordów kojarzą się ich przedstawiciele - lordowie, których prawo do zasiadania w izbie drugiej brytyjskiego parlamentu przez bardzo długi czas było związane z odziedziczonym tytułem szlacheckim. I choć dziś w skład Izby wchodzą różne kategorie parów, wciąż nawet w najmniejszym stopniu nie wywodzi się ona z wyborów rywalizacyjnych.

Dlatego też w klasyfikacjach izb drugich parlamentu występujących w państwach unitarnych Izba Lordów jest zaliczana do tzw. izb tradycyjnych, a zatem tych, które posiadają reprezentację subiektywną wynikającą ze stosowania technik pozaelekcyjnych, takich jak mianowanie, dziedziczenie itp. [Danel 2014: 190]. Jest to jedyna izba parlamentu w Europie, w której dominują członkowie pochodzący z nominacji. W gruncie rzeczy nawet poza Europą takich izb jest stosunkowo niewiele, a jeśli już, to zetkniemy się z nimi w krajach, w których, eufemistycznie rzecz ujmując, demokracja nie jest zbyt mocno zakorzeniona, jak np. Bahrajn, Jemen, Oman czy Lesotho. Rzecz jasna taki, a nie inny sposób kreowania składu osobowego Izby Lordów wynika nie tylko z tradycji brytyjskiego i angielskiego parlamentaryzmu, lecz także jest uzasadniany chęcią uzyskania pożądanego charakteru reprezentacji. Reprezentacja ta ma być bowiem zupełnie inna niż w przypadku Izby Gmin, która - jako typowa izba pierwsza - jest zdominowana przez partie polityczne. Jednak nie tylko czynniki polityczne i partyjne mają tutaj znaczenie. W oczach Brytyjczyków Izba Lordów ma przede wszystkim odzwierciedlać pewne szczególne idee i wartości właściwe dla brytyjskiej tradycji oraz logiki ustrojowej [Danel 2014: 190].

Stąd też w skład Izby Lordów wciąż wchodzi grupa tzw. lordów duchownych (Lords Spiritual), którą stanowi 26 arcybiskupów i biskupów Kościoła anglikańskiego. Wciąż też, mimo iż po wejściu w życie reformy z 1999 roku 
miejsce w Izbie przestało podlegać dziedziczeniu ${ }^{1}$, zasiada w niej 92 tzw. parów dziedzicznych. Takich osobliwości dotyczących składu osobowego Izby Lordów jest znacznie więcej, cyklicznie wracają też dyskusje nad tym, że należałoby ten skład „zdemokratyzować”, czyli innymi słowy przekształcić Izbę Lordów w izbę parlamentu pochodzącą z wyborów - nawet jeśli nie bezpośrednich, to być może pośrednich. Nie brakuje też zwolenników całkowitej likwidacji Izby Lordów i przekształcenia brytyjskiego parlamentu w zgromadzenie unikameralne. Wydaje się jednak, że ani sposób kreowania składu osobowego Izby, ani obecność w niej poszczególnych kategorii parów nie stanowią dziś na tyle kontrowersyjnych kwestii, którymi chciano by się zająć w najbliższej przyszłości, zmierzając do przeprowadzenia kolejnej reformy ustrojowej.

Podobnie zresztą przedmiotem kontrowersji nie jest dziś i najprawdopodobniej nie będzie w najbliższym czasie zakres uprawnień Izby Lordów, a także jej pozycja ustrojowa jako jednej z izb brytyjskiego parlamentu. Panuje bowiem dość powszechne przekonanie, że Izba ta pełni w ramach brytyjskiego porządku konstytucyjnego bardzo pożyteczną rolę, realizując z powodzeniem wiele funkcji, które momentami nawet wykraczają poza klasyczny zestaw funkcji zgromadzeń parlamentarnych. Nie ulega żadnej wątpliwości, że dzięki Izbie Lordów parlament, będący dla Brytyjczyków absolutnie kluczową instytucją władzy publicznej, jest ciałem bardziej eksperckim, co pozytywnie wpływa na jakość stanowionego w nim prawa. Izba Lordów jest zatem cennym dopełnieniem Izby Gmin. Realizując swe funkcje, nie próbuje podważać nadrzędnej pozycji izby pierwszej czy też zaburzać asymetrii brytyjskiego bikameralizmu, jej działania nie prowadzą również do paraliżu prac parlamentu i rządu. Można zatem uznać, że pamiętne reformy z 1911 i 1949 roku, które w sposób istotny ograniczyły kompetencje i uprawnienia Izby Lordów w ramach realizowanej przez nią funkcji ustawodawczej, a co za tym idzie - w znacznym stopniu uformowały dzisiejszy kształt i charakter brytyjskiej dwuizbowości, nie wymagają pogłębienia czy też jakiejś szczególnej modyfikacji.

\section{LICZEBNOŚĆ IZBY LORDÓW - CHARAKTERYSTYKA PROBLEMU}

Obserwując sprawność funkcjonowania Izby Lordów, można dojść do wniosku, że to nie metody kształtowania składu osobowego czy też kompetencje Izby Lordów wzbudzają dziś coraz większe kontrowersje i wywołują coraz powszechniejsze dyskusje, ale jej liczebność. Aktualna liczba członków Izby Lordów wynosi 791 [UK Parliament Website], uwzględniając natomiast Lordów czasowo

1 Wyjątkiem od tej reguły są stanowiska Hrabiego Marszałka (Earl Marshal) oraz Lorda Wielkiego Szambelana (Lord Great Chamberlain), których miejsce w Izbie jest dziedziczone zgodnie z zasadą primogenitury. 
wyłączonych z członkostwa ${ }^{2}$, liczba ta rośnie do 815 . Pod tym względem Izba Lordów jest największą izbą parlamentu w Europie, a drugą największą na świecie, ustępując tylko jednoizbowemu parlamentowi chińskiemu, a zatem Ogólnochińskiemu Zgromadzeniu Przedstawicieli Ludowych, które ustawowo liczy 3000 członków. Wielka Brytania jest natomiast jedynym państwem na świecie o parlamencie dwuizbowym, w którym izba druga posiada większą liczbę członków niż izba pierwsza ${ }^{3}$. Izba Gmin liczy bowiem 650 posłów, a wszystko na to wskazuje, że od kolejnej kadencji będzie tych posłów $600^{4}$.

Liczba Lordów rzecz jasna zmieniała się na przestrzeni lat, absolutnie kluczowe jednak pod tym względem były reformy w drugiej połowie XX wieku, w tym przede wszystkim wprowadzenie Ustawy o Parostwach Dożywotnich z 1958 roku (Life Peerages Act 1958), która była zwieńczeniem kilkudziesięcioletnich dyskusji nad reformą składu osobowego Izby Lordów [Dymond 2008]. Na mocy tej ustawy Korona otrzymała możliwość kreacji parów dożywotnich, którzy stawali się pełnoprawnymi członkami Izby. Przełamało to absolutną dominację parów dziedzicznych, dając możliwość wejścia w skład Izby osobom w pewien szczególny sposób zasłużonym dla kraju, reprezentującym różne dziedziny życia społecznego. Po wejściu w życie tej ustawy po raz pierwszy również w Izbie Lordów mogły zasiąść kobiety5.

Końcówka lat 60. XX wieku upłynęła pod znakiem dyskusji nad dalszymi reformami Izby Lordów - i to zarówno jeśli chodzi o jej skład osobowy, jak i zakres kompetencji. Najbliższa realizacji była propozycja reformy autorstwa rządu Harolda Wilsona ${ }^{6}$, która jednak ostatecznie została spod obrad parlamentu wycofana, gdyż przeciwko niej wystąpił dość egzotyczny sojusz ,posłów z tylnych ław" (tzw. backbenchers) reprezentujących zarówno Partię Pracy, jak i Partię Konserwatywną [Danel 2014: 130]. Kolejne trzy dekady nieco wyhamowały zapędy reformatorskie w odniesieniu do drugiej izby brytyjskiego parlamentu - żaden rząd nie zdecydował się bowiem na przeprowadzenie praktycznie jakichkolwiek zmian i dopiero powrót do władzy laburzystów w 1997 roku przyniósł spodziewaną - choć i tak tylko częściową - reformę składu osobowego Izby Lordów. Częściową, gdyż z założeniu miał to być zaledwie pierwszy etap wielkiej reformy.

2 Są to lordowie przebywający na urlopie, pełniący ważne funkcje w organach władzy sądowniczej bądź też posłowie Parlamentu Europejskiego.

3 Jedynym parlamentem dwuizbowym, w ramach którego obie izby mają taką samą liczbę członków, jest parlament Bahrajnu - zarówno Zgromadzenie Narodowe, jak i Rada Szury liczą po 40 osób.

4 Jest to związane ze zmniejszeniem liczby jednomandatowych okręgów wyborczych, co wynika z Ustawy o Systemie Głosowania do Parlamentu oraz Okręgach Wyborczych z 2011 roku (Parliamentary Voting System and Constituencies Act 2011).

5 W odniesieniu do parostw dziedzicznych zmiana taka nastąpiła dopiero na mocy Ustawy o Parostwie z 1963 roku (Peerage Act 1963).

6 Mowa tutaj o Ustawie o Parlamencie z 1968 roku [Parliament (No. 2) Bill 1968]. 
Jednak, jak się później okazało, Partii Pracy - z różnych względów - nie udało się tej reformy dokończyć.

Niemniej jednak Ustawa o Izbie Lordów z 1999 roku (House of Lords Act 1999) doprowadziła do usunięcia z Izby ok. 660 parów dziedzicznych, co oznaczało, że jej rozmiar skurczył się praktycznie o połowę. W czerwcu 2000 roku uprawnionych do zasiadania w Izbie było już „zaledwie” 695 parów [Cracknell 2000]. Jak już wspomniano, ani Tony'emu Blairowi, ani jego następcy na stanowisku premiera - Gordonowi Brownowi - nie udało się przeprowadzić drugiego etapu reformy, mimo iż zostało w tej sprawie powołanych kilka specjalnych komisji, grup roboczych czy zespołów, a efekty ich prac opublikowano w postaci kilku tzw. Białych Ksiąg.

Ostatnia próba kompleksowej reformy składu osobowego Izby Lordów miała miejsce w czasach rządu koalicyjnego Partii Konserwatywnej z Liberalnymi Demokratami, a firmowana była nazwiskiem ówczesnego wicepremiera - Nicka Clegga. Rządowy projekt ustawy w tej sprawie, który został wprowadzony pod obrady parlamentu końcem czerwca 2012 roku, zakładał utworzenie 450-osobowej Izby Lordów, której 360 członków (80\%) miało pochodzić z wyborów, a $90(20 \%)$ - z nominacji. Ograniczeniu miała także ulec liczba lordów duchownych. Ponadto projekt ten - po raz pierwszy w historii - zakładał określenie długości kadencji członków Izby Lordów, która miała wynosić 15 lat [Bowers, Gay, Kelly 2012]. Wskutek oporu pokaźnej grupy posłów Partii Konserwatywnej, a także braku sprzyjających okoliczności politycznych Nick Clegg został zmuszony do wycofania tego projektu ustawy, co oznaczało, że kolejna próba reformy składu osobowego Izby Lordów została zaprzepaszczona.

Ostatnie 5 lat upłynęło pod znakiem dalszych dyskusji i debat, które doprowadziły do niewielkich zmian ustawowych związanych z członkostwem w Izbie Lordów. I choć zmiany te były ważne i potrzebne, trudno uznać je za rewolucyjne - zwłaszcza biorąc pod uwagę skalę całego problemu. W roku 2014 weszła w życie Ustawa o Reformie Izby Lordów (House of Lords Reform Act 2014), która dała lordom możliwość przejścia na emeryturę bądź dobrowolnego zrezygnowania z miejsca w Izbie. Nawet jeśli trudno w to uwierzyć, z prawnego punktu widzenia wcześniej takich możliwości nie było ${ }^{7}$. Na koniec czerwca 2018 roku z możliwość takiej skorzystało już 84 parów $^{8}$. Ustawa z 2014 roku umożliwia również wykluczenie z Izby Lordów tych jej członków, którzy popełnili poważne przestępstwa, których skutkiem jest co najmniej roczny wyrok pozbawienia wolności, oraz członków, którzy nie uczestniczą w obradach Izby przez cały czas

7 Nie licząc wprowadzonego pozaustawowo rezolucją Izby z 27 czerwca 2011 roku dobrowolnego programu przechodzenia na emeryturę (voluntary retirement scheme), z którego jednak i tak skorzystało zaledwie 4 parów.

8 UK Parliament Website, https://www.parliament.uk/mps-lords-and-offices/lords/retired-lords/ [dostęp: 29.06.2018]. 
trwania jej sesji甲 ${ }^{9}$. Na podstawie tego przepisu na koniec czerwca 2018 roku z Izby Lordów wykluczono 6 parów ${ }^{10}$.

Niejako w uzupełnieniu w 2015 roku weszła z kolei w życie ustawa ${ }^{11}$, która rozszerza wachlarz możliwości wykluczenia z Izby poza te wskazane w ustawie z 2014 roku (dając możliwość szczegółowego określenia takich okoliczności w regulaminie obrad Izby), a także umożliwia zawieszenie w prawach członka na czas przekraczający kadencję parlamentu (wcześniej - w określonych okolicznościach - Izba miała prawo zawieszenia swego członka na określony czas, choć nie dłużej, niż do końca danej kadencji parlamentu). Jak do tej pory przepisy tej ustawy nie znalazły zastosowania.

Dla porządku warto jeszcze wspomnieć o ustawie, na mocy której lordami duchownymi mogą być również kobiety ${ }^{12}$, co było bezpośrednim następstwem bezprecedensowej zgody Kościoła anglikańskiego na to, aby stanowiska biskupów mogły obejmować właśnie kobiety.

Wszystkie te zmiany i reformy - choć ważne i idące z duchem czasu - nie rozwiązały jednak kluczowego problemu Izby Lordów, a zatem rosnącej liczby jej członków. Choć po wejściu w życie Ustawy o Izbie Lordów z 1999 roku w Izbie pozostało ok. 700 członków, liczba ta zaczęła z czasem gwałtownie rosnąć. Było to rzecz jasna efektem kreacji nowych parostw dożywotnich przez szefów brytyjskich rządów (przede wszystkim przez Davida Camerona, który w samym 2010 roku przyznał takie parostwo 117 osobom) [Blocklehurst, Kelly 2012], gdyż w tym zakresie nadal posiadają oni praktycznie nieograniczone możliwości. Na to, że sytuacja ta wymaga nowych regulacji prawnych i podjęcia natychmiastowych działań, eksperci od prawa konstytucyjnego zwracali uwagę już w 2011 roku, gdy liczba członków Izby Lordów przekroczyła 800. Przestrzegali przy tym, że tak szybko rozszerzający się skład Lordów może wkrótce doprowadzić do kompletnego paraliżu jej prac, niemożności realizowania jej zasadniczych funkcji oraz wykonywania powierzonych jej zadań [Russell 2011: 3]. Ich apele nie zostały jednak przez polityków wysłuchane.

\section{DEBATA W IZBIE LORDÓW ORAZ RAPORT KOMISJI LORDA SPIKERA}

Początkiem 2015 roku wybitna badaczka brytyjskiego systemu konstytucyjnego Meg Russell zwróciła uwagę, że od 2000 roku liczba członków Izby Lordów wzrosła o ok. 1/3, osiągając 850 [Russell, Semlyen 2015: 4]. Pomijając wspomniane wcześniej wątpliwości natury ogólnej, dotyczące zasadności utrzymywa-

${ }^{9}$ House of Lords Reform Act 2014.

10 UK Parliament Website, https://www.parliament.uk/mps-lords-and-offices/lords/non-attendance/ [dostęp: 29.06.2018].

11 House of Lords (Expulsion and Suspension) Act 2015.

${ }^{12}$ Lords Spiritual (Women) Act 2015. 
nia ponad 800-osobowego parlamentu, sytuacja ta rodzi wiele różnego rodzaju problemów technicznych. Otóż po pierwsze na sali posiedzeń Izby Lordów, gdzie miejsca siedzące nie są przypisane do konkretnych osób, zaczęło tych miejsc po prostu brakować ${ }^{13}$. W Pałacu Westminsterskim natomiast (a także innych okolicznych budynkach wykorzystywanych przez Izbę) przestało wystarczać przestrzeni biurowej dla samych lordów, a także dla personelu administracyjnego Izby. Taki stan rzeczy generuje dodatkowe koszty, a to zupełnie przestało się wpisywać w debatę nad koniecznością ograniczania wydatków publicznych, odchudzania administracji państwowej itp. Warto też zwrócić uwagę na to, że im większa liczba lordów, tym potencjalnie dłużej trwają same obrady, gdyż więcej osób chce zabrać głos w dyskusji czy zadać pytanie, co (nie tylko w teorii, ale również w praktyce) może prowadzić do paraliżu prac Izby, a co za tym idzie - całego parlamentu.

Problem ten stał się przedmiotem prac zarówno komisji parlamentarnych (np. Komisji ds. Reformy Politycznej i Konstytucyjnej Izby Gmin), jak i niezależnych grup eksperckich skupionych wokół ośrodków akademickich czy politycznych think tanków. Zdecydowana większość propozycji i rekomendacji wynikających z różnego rodzaju raportów przygotowanych przez te podmioty sprowadzała się do tego, że należy w sposób zdecydowany zreformować system kreowania nowych parostw dożywotnich, gdyż to on stanowi główne źródło problemu. To bowiem szefowie rządów w gruncie rzeczy kontrolują rozmiar Izby Lordów, a także - w zależności od swych politycznych potrzeb - mogą manipulować partyjnym składem Izby w sytuacji, gdy przykładowo nastąpi konieczność wzmocnienia rządu i osłabienia opozycji. Brak uregulowania tej kwestii, a zatem określenia kiedy i w jakiej ilości szefowie rządów mogą kreować nowe parostwa dożywotnie (a także ustanowienia limitu określającego maksymalną liczbę członków Izby Lordów) czyni zatem wszelkie inne działania, jak choćby te dotyczące możliwości dobrowolnego przechodzenia na emeryturę, nieskutecznymi i połowicznymi [Russell, Semlyen 2015: 5].

W związku z zakończeniem kadencji parlamentu i rozpisaniem nowych wyborów do Izby Gmin końcem sierpnia 2015 roku powołano 45 nowych parów dożywotnich (na podstawie tzw. dissolution honours list). Rezygnacja Davida Camerona z funkcji premiera w lipcu 2016 roku doprowadziła do kreacji kolejnych 16 parostw (na podstawie tzw. resignation honours list). Kluczowa w dyskusji nad tym problemem okazała się debata przeprowadzona w Izbie Lordów 5 grudnia 2016 roku. Zabrało w niej głos aż 61 mówców, a lordowie jednogłośnie (bez głosowania) przyjęli wniosek Lorda Cormacka, iż: „Izba jest przekonana, że jej rozmiar powinien być zredukowany oraz powinny zostać określone metody w jaki sposób może to zostać osiągnięte" [Kelly 2017: 16]. Dwa tygodnie później - 20 grudnia 2016 roku - Lord Spiker (lord Norman Fowler) ogłosił powołanie

${ }^{13}$ Zauważalna stała się rosnąca frekwencja na modlitwach rozpoczynających każde posiedzenie Izby. Nie wynika to bynajmniej z nagłego wzrostu religijności wśród lordów, ale z chęci zajęcia sobie miejsca siedzącego na nadchodzące obrady. 
6-osobowej komisji złożonej z lordów z tylnych ław (tzw. backbenchers). Przewodniczącym komisji został lord Terence Burns, a jej zadanie polegało na określeniu metod rozwiązania problemu nadmiernej liczby członków Izby Lordów. Warto w tym miejscu podkreślić, że nie była to komisja powołana z inicjatywy rządu, ale firmowana nazwiskiem samego Lorda Spikera (Lord Speaker's Committee on the Size of the House), co nadało jej pewnego szczególnego prestiżu. Jej prace trwały niecały rok, a raport będący ich zwieńczeniem ${ }^{14}$ opublikowano 31 października 2017 roku.

Najważniejsze rekomendacje zawarte w raporcie są następujące:

1) Izba Lordów powinna docelowo liczyć 600 członków;

2) wszyscy nowi członkowie Izby Lordów powinni mieć prawo do zasiadania w niej przez jedną, nieodnawialną, 15-letnią kadencję, co ma zapewnić rotację lordów niezbędną do odpowiedniego zbalansowania partyjnego Izby;

3) parowie niezależni (tzw. crossbenchers) powinni nadal stanowić podobną proporcję wszystkich parów $(\min .20 \%)^{15}$;

4) docelowo nowe parostwa dożywotnie powinny być dzielone pomiędzy partie zgodnie z ich wynikami w ostatnich wyborach do Izby Gmin (proporcjonalnie do liczby uzyskanych przez nich mandatów oraz określonego procentowo wyniku w skali całego kraju).

Założenie raportu jest takie, że wszystkie wyżej wymienione propozycje mogłyby wejść w życie bez konieczności wprowadzania jakichkolwiek zmian w prawie, a jeśli tak, to nie mogą one dotyczyć ani lordów duchownych, ani parów dziedzicznych, gdyż w tych przypadkach konieczna byłaby zmiana obowiązujących ustaw ${ }^{16}$.

Nie jest oczywiście możliwe, aby osiągnąć pułap 600 członków Izby od razu, zatem dopóki tak się nie stanie, w miejsce każdych dwóch Lordów opuszczających Izbę powinien być powoływany jeden nowy (reguła two out-one in). Po dojściu do liczby 600, powstające wakaty (komisja oszacowała, że będzie ich ok. 40 rocznie) powinny być uzupełniane dokładnie taką samą liczbą nowych lordów. Autorzy raportu przekonywali, że gdyby ich rekomendacje udało się jeszcze w 2017 roku wprowadzić w życie, ok. 11 lat byłoby potrzebne, aby liczba

${ }^{14}$ Report of the Lord Speaker's committee on the size of the House, 31 October 2017, https:// www.parliament.uk/documents/lords-committees/size-of-house/size-of-house-report.pdf [dostęp: 22.06.2018].

${ }^{15}$ Uzupełnianie wakatów w tej grupie parów miałoby nadal pozostać w gestii Komisji ds. Nominacji do Izby Lordów (House of Lords Appointments Commission) oraz premierów brytyjskich rządów, choć należałoby bardziej precyzyjnie określić kryteria umożliwiające ubieganie się o takie parostwo.

${ }^{16} \mathrm{~W}$ przypadku lordów duchownych liczbę 26 reguluje Ustawa o Biskupstwie Manchesteru z 1847 roku (Bishopric of Manchester Act 1847), 92 parów dziedzicznych zostało natomiast wpisanych we wspomnianą już Ustawę w Izbie Lordów z 1999 roku (House of Lords Act 1999). Autorzy raportu podkreślają natomiast, że przy braku jakichkolwiek zmian w odniesieniu do tych dwóch grup parów byłyby one w Izbie Lordów procentowo nieco silniej reprezentowane niż ma to miejsce obecnie. 
członków Izby Lordów osiągnęła pożądane 600 osób. Już po 2032 roku pierwsi lordowie kończyliby swą 15-letnią kadencję, z kolei po 2042 roku wszyscy z nich objęci byliby już 15-letnią kadencją [Report of the Lord... 2017: 25]. Wydaje się zatem, że najtrudniejszy byłby właśnie ten okres przejściowy, gdyż - zgodnie z nakreślonym harmonogramem - każda grupa lordów musiałaby w danym roku kalendarzowym przekonać określoną liczbę swych członków do przejścia na emeryturę lub rezygnacji z członkostwa w Izbie. Redukcja ta miałaby objąć proporcjonalnie równą część członków poszczególnych grup.

Zmieniony musiałby zostać również regulamin obrad izby (Standing Orders) oraz tzw. Kodeks Postępowania (Code of Conduct), gdyż nowi parowie musieliby podpisywać zobowiązanie, że po 15 latach złożą rezygnację z członkostwa w Izbie ${ }^{17}$. Złamanie takiego zobowiązania oznaczałoby naruszenie Kodeksu Postępowania, co z kolei skutkowałoby wykluczeniem danego lorda z Izby na mocy uprawnień nadanych Izbie przez wspominaną wcześniej ustawę z 2015 roku [House of Lords (Expulsion and Suspension) Act 2015].

Najbardziej problematyczna, a zarazem newralgiczna wydaje się jednak kwestia politycznej równowagi w Izbie Lordów i zapewnienie by, po pierwsze, żadna partia nie dysponowała w niej absolutną większością, po drugie zaś, by polityczny układ sił w Izbie Lordów był nieco bardziej niż dziś zbliżony do politycznego układu sił w Izbie Gmin (choć też by nie był jego prostym odzwierciedleniem). Stąd właśnie zaproponowana formuła, aby kreacja nowych parostw dożywotnich musiała odzwierciedlać zmieniające się poparcie dla poszczególnych partii politycznych wyrażone ich wynikiem w wyborach do Izby Gmin. Wziąwszy jednak pod uwagę, że obowiązująca w tych wyborach zasada większości względnej (tzw. first past the post) w sposób mocno niedoskonały oddaje poziom realnego poparcia społecznego, autorzy raportu zasugerowali, aby dla wyliczenia tych proporcji zastosować formułę łączącą liczbę uzyskanych mandatów oraz procentowy wynik wyborczy danej partii w skali kraju.

\section{PYTANIA O ZASADNOŚĆ REFORMY I SZANSE JEJ POWODZENIA}

Przedstawiony powyżej raport stanowi najbardziej kompleksową propozycję reformy Izby Lordów od czasów projektu ustawy przygotowanej przez koalicyjny rząd Partii Konserwatywnej i Liberalnych Demokratów, który to projekt ostatecznie upadł w 2012 roku. Jego niewątpliwą zaletą jest to, że jest firmowany autorytetem samego Lorda Spikera, a zatem jest to propozycja samych Lordów, a nie rządu, opozycji czy którejś z partii politycznych. Po drugie - co również należy w sposób bardzo wyraźny podkreślić - rekomendacje zawarte w raporcie

17 Podobna zasada miałaby dotyczyć także nowych parów dziedzicznych, którzy wejdą w skład Izby zgodnie z obowiązującą procedurą, a zatem w drodze dość specyficznych wyborów uzupełniających. 
mają na celu nie tyle doprowadzenie do jakiejś kompleksowej czy też radykalnej (w znaczeniu prawno-konstytucyjnym) reformy Izby Lordów, ale rozwiązanie jednego konkretnego problemu, jakim jest zbyt duża liczba jej członków. Ta kwestia bowiem, a nie uprawnienia izby drugiej brytyjskiego parlamentu czy też jej pozycja w ramach brytyjskiego porządku konstytucyjnego wywołuje dziś kontrowersje i jest przedmiotem debaty publicznej. Zresztą z historycznego punktu widzenia powodzeniem kończyły się z reguły te propozycje reformy Izby Lordów, które właśnie miały za zadanie rozwiązywać konkretny problem, uznany w danej chwili za priorytetowy.

Analizowany raport koncentruje się zatem na tych zmianach, które można przeprowadzić stosunkowo szybko i co więcej - nie są to zmiany wymagające przyjęcia przez parlament nowej ustawy. Prace nad projektami ustaw o charakterze konstytucyjnym są zawsze czasochłonne, a w tym konkretnym przypadku politycy brytyjscy muszą działać bez zbędnej zwłoki. $Z$ formalnego punktu widzenia, aby rekomendacje Komisji Lorda Spikera weszły w życie, wystarczy odpowiednia zmiana wewnętrznych dokumentów, na podstawie których funkcjonuje Izba Lordów, a zatem regulaminu jej obrad oraz Kodeksu Postępowania. Ten brak umocowania $\mathrm{w}$ ustawie nadaje również tym propozycjom pewną elastyczność w tym sensie, że w razie gdyby okazało się, że na etapie realizacji coś pójdzie inaczej niż przewidywano (bądź też pojawią się innego rodzaju komplikacje), równie łatwo będzie można wprowadzić do tej reformy odpowiednią korektę, a nawet ją unieważnić. W każdej zresztą chwili rząd będzie miał możliwość zaproponować, za pomocą własnego projektu ustawy, jakieś alternatywne rozwiązanie. Premier natomiast formalnie i tak zachowa swoje niczym nieograniczone uprawnienia do kreowania nowych parostw dożywotnich, z których to uprawnień będzie mógł skorzystać w sytuacji blokowania przez Izbę Lordów rządowych projektów ustaw [Russell 2017].

Wspomniana powyżej elastyczność, a zwłaszcza brak umocowania w ustawie są także interpretowane jako słabość proponowanej reformy. W gruncie rzeczy jej powodzenie byłoby bowiem uzależnione od dobrej woli samych Lordów, a przede wszystkim partyjnych liderów, którzy musieliby zarówno wzajemnie przed sobą, jak i przed opinią publiczną zobowiązać się, że będą przestrzegać ustalonych reguł. Dla premiera z kolei (i aktualnego, i każdego kolejnego) oznaczałoby to konieczność dobrowolnego podporządkowania się nowym zasadom dotyczącym kreowania parostw dożywotnich, co w pewnym sensie oznaczałoby znaczące ograniczenie tego bardzo tradycyjnego uprawnienia szefów brytyjskich rządów. I choć akurat w przypadku Wielkiej Brytanii, biorąc pod uwagę jej kulturę polityczną, a także fakt, że opinia społeczna jest w stanie w sposób skuteczny wywrzeć na polityków presję, można sobie taki scenariusz wyobrazić, to uzależnienie jakichkolwiek działań jedynie od dobrej woli polityków oraz brak zabezpieczenia ich od strony prawnej zawsze będzie oznaką ich słabości i ulotności. Tego rodzaju wątpliwości zostały podniesione zresztą przez niektórych Lordów w trakcie debaty nad Raportem Komisji Lorda Spikera, która odbyła się 
w Izbie 19 grudnia 2017 roku. Zwracali oni uwagę na to, że w gruncie rzeczy i tak są to propozycje, które powodowałyby zmiany o charakterze konstytucyjnym, a jeśli tak - wymagałyby one umocowania w ustawie oraz akceptacji ze strony Izby Gmin, rządu, a nawet samego elektoratu [Russell 2017]. Z dość szeroką krytyką - mimo stosunkowo powszechnego poparcia dla rekomendacji zawartych w raporcie - spotkał się również brak propozycji ostatecznego pozbycia się z Izby parów dziedzicznych oraz ewentualnego zmniejszenia liczby lordów duchownych. I choć wiadomo, że tego rodzaju zmiany musiałyby znaleźć oparcie w ustawie, wielu Lordów uważa je za absolutnie kluczowe. Rozczarowania propozycjami Komisji nie kryły również różnego rodzaju polityczne grupy nacisku (np. Electoral Reform Society lub Unlock Democracy), które utrzymują, że Izba Lordów jest instytucją niedemokratyczną, która wymaga kompleksowej reformy i dostosowania do realiów politycznych charakterystycznych dla nowoczesnych demokracji [Kelly 2017: 12-13].

W swym manifeście wyborczym, zarówno z 2015, jak i z 2017 roku, Partia Konserwatywna ograniczyła się do dość ogólnikowych sformułowań na temat Izby Lordów, podkreślając jednocześnie, że jej reforma nie jest dla torysów sprawą priorytetową. Jednakże publikacja Raportu Komisji Lorda Spikera zmusiła Theresę May do zajęcia oficjalnego stanowiska w tej sprawie. W liście przesłanym na ręce Lorda Spikera 20 lutego 2018 roku premier brytyjskiego rządu przyznała, że istnieje powszechna zgoda co do tego, że zmniejszenie liczby członków Izby Lordów jest sprawą pilną. Niemniej jednak w sposób wyraźny dała do zrozumienia, że niektóre z propozycji zawartych w raporcie (zwłaszcza te dotyczące zasad, według których docelowo będzie funkcjonować 600-osobowa Izba Lordów, np. wprowadzenia 15-letniej kadencji dla nowych parów) wymagają dalszej dyskusji tak, aby nie wywołały one niezamierzonych skutków ${ }^{18}$.

Theresa May podkreśliła również, że osobiście wykazuje daleko idącą wstrzemięźliwość, jeśli chodzi o powoływanie w skład Izby nowych parów dożywotnich, gdyż odkąd w lipcu 2016 roku została premierem w Izbie Lordów pojawiło się 24 nowych parów dożywotnich (w tym 16 jeszcze decyzją jej poprzednika Davida Camerona) oraz 2 nowych parów dziedzicznych. W tym samym czasie szeregi Izby - czy to dzięki odejściu na emeryturę, usunięciu z Izby czy też z przyczyn naturalnych - opuściło 46 parów. Zdaniem premier brytyjskiego rządu, warunkiem powodzenia całej operacji jest więc utrzymanie takiej tendencji (do czego się zobowiązała, choć równocześnie zapowiedziała nowe kreacje parów dożywotnich), przy jednoczesnym zapewnieniu liderów wszystkich partii reprezentowanych w Izbie Lordów (a także grupy parów niezależnych), że podejmą działania nakłaniające poszczególnych Lordów do przechodzenia na emeryturę ${ }^{19}$.

18 UK Parliament Website, https://www.parliament.uk/documents/lords-information-office/2018/The\%20Lord\%20Fowler_001.pdf [dostęp: 21.06.2018].

${ }_{19}$ Ibidem. 


\section{KONKLUZJE}

Nie sposób jednoznacznie odpowiedzieć na pytanie, czy w najbliższej przyszłości czeka nas kolejna reforma składu osobowego brytyjskiej Izby Lordów. O tym, że reforma taka jest niezbędna, przekonali się nawet sami lordowie, ale długa historia brytyjskiego (a wcześniej angielskiego) parlamentaryzmu pokazuje nam, jak trudno w tym kraju przeprowadzić jakiekolwiek reformy o charakterze ustrojowym. Przeprowadzona w artykule analiza zapisów Raportu Komisji Lorda Spikera, a także reakcji polityków na jego publikację potwierdza tezę, że bardzo mało prawdopodobne jest, aby reforma Izby Lordów weszła w życie w kształcie zaproponowanym w tym raporcie. Wiele wskazuje na to, że harmonogram oraz tempo zaproponowanych zmian są mało realistyczne, choć z drugiej strony można też powiedzieć, że jest to tylko pewna kierunkowa propozycja, która nie musi zostać dokładnie w ten sposób zrealizowana. Najważniejsze jest osiągnięcie celu. Czy zatem uda się ten cel osiągnąć za pomocą zaproponowanych działań? Także i tutaj można mieć sporo wątpliwości, gdyż wydaje się - biorąc pod uwagę choćby wcześniejsze doświadczenia brytyjskie - że tego rodzaju zmiany ustrojowe zdecydowanie łatwiej i skuteczniej przeprowadzić w formie ustawy, a nie polegając jedynie na dobrej woli polityków.

Podkreślić również trzeba na koniec uwarunkowania polityczne - zarówno wewnętrzne, jak i międzynarodowe. Nie można zapominać o tym, że od czerwca 2017 roku rząd tworzony przez Partię Konserwatywną jest rządem mniejszościowym. Trudno się zatem spodziewać, by jakoś szczególnie angażował się w działania, które co prawda popiera (o czym świadczy cytowany powyżej list premier May), ale których realizacja najzwyczajniej w świecie może poczekać na lepszy moment. Tym bardziej że od końca czerwca 2016 roku tematem numer jeden dla brytyjskich polityków jest Brexit, czyli wyjście Wielkiej Brytanii z Unii Europejskiej. To działania i decyzje związane z tym procesem są na tyle priorytetowe, że nawet reformy o charakterze ustrojowym czy konstytucyjnym muszą zejść na drugi plan albo wręcz zostać podporządkowane potrzebom chwili. Najlepszym na to dowodem jest to, że 18 maja 2018 roku Theresa May powołała w skład Izby Lordów 13 nowych parów dożywotnich, w tym 9 reprezentujących Partię Konserwatywną. Decyzja ta była bezpośrednią konsekwencją kilkunastu poprawek złożonych przez Lordów do rządowej Ustawy o Wystąpieniu z Unii Europejskiej [European Union (Withdrawal) Act 2018]. Chęć swoistego postraszenia Lordów (co jest tradycyjnym narzędziem w rękach premiera) i pokazania im, że w razie potrzeby rząd może powołać tylu nowych parów, aby złamać upór Izby, w sposób wyraźny wzięła górę nad deklarowaną wstrzemięźliwością, jeśli chodzi o kreowanie nowych parostw. 
Title: Reform of the British House of Lords in the Light of the Report of the Lord Speaker's Committee 2017

Summary: The article is dedicated to the analysis of the latest concept regarding the reform of the House of Lords. This concept appeared in October 2017 with the publication of the Report of the Lord Speaker's Committee. The Report contains recommendations aimed at limiting the number of members of the House of Lords, as this is a fundamental problem that this chamber of the British Parliament is currently facing.

The author begins by analyzing the actual state and circumstances that led to a revival of the discussion on the reform of the House of Lords. Then he presents the most important assumptions of the Lord Speaker's Committee, evaluates them, and tries to prove the thesis that they are unlikely to come into force, at least in this form. This is due to both internal conditions related to the British constitutional order and external conditions, because today the United Kingdom faces great challenges on the international arena, through which the challenges of constitutional changes are considered to be secondary in the eyes of British politicians.

Keywords: reform, House of Lords, parliament, Great Britain, tradition, constitution

\section{BIBLIOGRAFIA}

1. Bowers P., Gay O., Kelly R. (2012), House of Lords Reform Bill 2012-13. Bill No 52 2012-13, House of Commons Library, Research Paper 12/37.

2. Brocklehurst A., Kelly R. (2012), Peerage Creations since 1997, House of Lords Library Note, LLN 2012/023.

3. Cracknell R. (2000), Lords Reform: The interim House - background statistics, House of Commons Library, Research Paper 00/61.

4. Danel Ł. (2014), Izba Lordów w parlamentaryzmie brytyjskim, Wydawnictwo Sejmowe, Warszawa.

5. Dymond G. (2008), The Life Peerages Act 1958, House of Lords Library Note LLN 2008/011.

6. House of Lords (Expulsion and Suspension) Act 2015.

7. House of Lords Reform Act 2014.

8. Kelly R. (2017), House of Lords Reform in the 2017 Parliament, House of Commons Library, Briefing Paper 08137.

9. Lords Spiritual (Women) Act 2015.

10. Parliament (No. 2) Bill 1968.

11. Parliamentary Voting System and Constituencies Act 2011.

12. Peerage Act 1963.

13. Report of the Lord Speaker's committee on the size of the House, 31 October 2017, https:// www.parliament.uk/documents/lords-committees/size-of-house/size-of-house-report.pdf [dostęp: 22.06.2018].

14. Russell M. (2017), The size of the House of Lords: what next?, The Constitution Unit, UCL London, https://constitution-unit.com/2017/12/22/the-size-of-the-house-of-lords-what-next/ [dostęp: 21.06.2018].

15. Russell M. (2011), House Full: Time to get a grip on Lords appointments, The Constitution Unit, UCL London. 
16. Russell M., Semlyen T. (2015), Enough is enough. Regulating prime ministerial appointments to the Lords, The Constitution Unit, UCL London.

17. UK Parliament Website, https://www.parliament.uk/documents/lords-information-office/2018/ The\%20Lord\%20Fowler_001.pdf [dostęp: 21.06.2018].

18. UK Parliament Website, https://www.parliament.uk/mps-lords-and-offices/lords/composition-of-the-lords/ [dostęp: 29.06.2018].

19. UK Parliament Website, https://www.parliament.uk/mps-lords-and-offices/lords/non-attendance/ [dostęp: 29.06.2018].

20. UK Parliament Website, https://www.parliament.uk/mps-lords-and-offices/lords/retired-lords/ [dostęp: 29.06.2018]. 